\title{
PENGARUH KONSELING COGNITIVE BEHAVIOR TEKNIK COGNITIVE RESTRUCTURING UNTUK MEREDUKSI KECEMASAN SOSIAL SISWA
}

\author{
Iis Pujiati ${ }^{1)}$, Harwanti Noviandari ${ }^{2)}$ \\ Fakultas Keguruan dan Ilmu Pendidikan, Universitas PGRI Banyuwangi \\ Email : ipiniiz@yahoo.co.id ${ }^{1}$ \\ Email : hnoviandari83@gmail.com²
}

\begin{abstract}
Abstrak
Kecemasan merupakan suatu pengalaman subjektif mengenai ketegangan mental dan yang menggelisahkan sebagai reaksi umum dan ketidak mampuan menghadapi masalah atau adanya rasa aman. Kecemasan ini seringkali diabaikan dan sebagian besar dianggap siswa tidak memiliki masalah yang serius, padahal jika masalah kecemasan ini dibiarkan berkepanjangan dan siswa tidak mampu mengatasinya, maka dapat berakibat pada kesulitan dalam melakukan komunikasi interpersonal, sulitnya mengungkapkan pendapat dan prestasi belajar menurun. Penelitian ini bertujuan untuk mengetahui pengaruh konseling cognitive behavior dengan teknik cognitive restructuring untuk mereduksi kecemasan sosial siswa kelas X SMA Negeri Darussholah Singojuruh. Metode yang digunakan dalam penelitian ini adalah desain eksperimen dengan menggunakan rancangan control group pratest and posttest design. Sampel penelitian sebanyak 15 orang siswa yang memiliki perilaku kecemasan sosial. Teknik pengambilan sampel menggunakan sampel purposive. Dalam penelitian ini analisis data menggunakan analisis data statistik kuantitatif.
\end{abstract}

Kata Kunci : Cognitve Behavior, Kecemasan Sosial, Cognitive Restructuring.

\begin{abstract}
Abstrac
Anxiety is a subjective experience of mental tension and anxiety as a general reaction and an inability to deal with a problem or a sense of security. These anxieties are often ignored and most are considered to have no serious problems, whereas if the anxiety problem is left prolonged and students are unable to cope, it can result in difficulty in interpersonal communication, the difficulty of expressing declining opinions and learning achievement. This study aims to determine the effect of cognitive behavior counseling with cognitive restructuring techniques to reduce social anxiety of class $X$ students of SMA Negeri Darussholah Singojuruh. The method used in this research is experimental design using control group pratest and posttest design. The sample of the study were 15 students who had social anxiety behavior. The sampling technique used purposive sample. In this study data analysis using quantitative statistical data analysis.
\end{abstract}

Keyword: Cognitve Behavior, Dread Of Social, Cognitive Restructuring.

1. PENDAHULUAN
Pendidikan memiliki peranan yang sangat penting bagi individu. Peran pendidikan yaitu untuk mencetak sumber daya manusia 
(SDM) yang berkualitas tinggi dan memiliki daya saing yang tinggi pula dalam upaya meningkatkan kualitas kehidupan, dalam upaya meningkatkan kualitas kehidupan, penguasan bidang ilmu dan teknologi dalam kadar yang memadai sangat diperlukan agar masyarakat dapat meningkatkan kemampuan kreativitas, pengembangan, dan penerapan iptek (ilmu pengetahuan dan teknologi) sebagai tuntutan yang mutlak dalam kehidupan global (Hatten dan Resenthal dalam Karwati 2016). Peserta didik memerlukan adanya kecakapan dalam berkomunikasi untuk meningkatkan kemampuan relasi terhadap masyarakat luas. Sebagai makhluk sosial, manusia dituntut untuk mampu berinteraksi dan berkomunikasi dengan orang lain untuk memenuhi kebutuhannya dalam kelangsungan hidupnya.

Kenyataan yang terlihat, tidak semua individu dapat berkomunikasi secara lancar dengan orang lain. Hal ini terjadi baik dalam kegiatan belajar mengajar (KBM) di sekolah maupun di luar sekolah. Hambatan yang dialami individu dalam berkomunikasi yaitu adanya kecemasan dalam dirinya. Kecemasan merupakan suatu pengalaman subjektif mengenai ketegangan mental dan yang menggelisahkan sebagai reaksi umum dan ketidak mampuan menghadapi masalah atau adanya rasa aman. Kecemasan ini seringkali diabaikan dan sebagian besar dianggap siswa tidak memiliki masalah yang serius, padahal jika masalah kecemasan ini dibiarkan berkepanjangan dan siswa tidak mampu mengatasinya, maka dapat berakibat pada kesulitan dalam melakukan komunikasi interpersonal, sulitnya mengungkapkan pendapat dan prestasi belajar menurun. Akibatnya, Individu yang mengalami kecemasan sosial akan berpikir evaluasi negatif yang dilakukan oleh seseorang terhadap dirinya baik nyata maupun prasangka dan untuk menghindari diri dari kecemasan ini, sehingga individu akan memunculkan rasa aman dalam Swasti \& Wisjnu(2013).
Adanya masalah-masalah sosial yang dialami siswa dapat mengakibatkan timbulnya perasaan terasing, keputusasaan, problem identitas dan masalah-masalah yang berhubungan dengan ketidak mampuan dalam menyesuaikan diri dengan lingkungan sosial, di dalam hal ini maka yang sangat dibutuhkan siswa dalam menjalin hubungan sosial adalah interaksi sosial yang baik, sehingga dapat menghindari berbagai pikiran serta perasaan negatif yang dapat memberikan efek buruk bagi pertumbuhan dan perkembangan siswa menuju dewasa. Oort et al (2011) menyatakan bahwa hasil penelitian yang dilakukan pada 2 , 220 remaja laki- laki dan perempuan yang mengalami gejala kecemasan menemukan faktor seperti penolakan dari orang tua adalah indikator kecemasan pada masa remaja awal, sedangkan faktor-faktor lain seperti penganiayaan dari teman sebaya adalah indikator kecemasan pada jangka panjang. Merasa cemas pada situasi tertentu merupakan sesuatu yang wajar, tetapi apabila kecemasan tersebut menjadi parah dan menyebabkan gejala-gejala kecemasan muncul di kehidupan sehari-hari maka individu disebut mengalami gangguan kecemasan sosial (LaFarr, 2010). Kecemasan sosial menurut Dayakisni dan Hudainah (2009) adalah perasaan tidak nyaman akan kehadiran orang lain, yang selalu disertai perasaan malu yang ditandai dengan kejanggalan atau kekakuan, hambatan dan kecenderungan untuk menghindari situasi sosial. Berdasarkan hasil penelitian tersebut dapat disimpulkan bahwa dengan adanya perilaku kecemasan sosial yang dialami individu dapat menyebabkan individu tersebut mengalami tekanan yang berdampak pada kehidupan sosialnya, karena pada dasarnya manusia adalah mahluk sosial yang artinya dia tidak dapat hidup tanpa orang lain.

Berdasarkan hasil wawancara yang dilakukan penulis kepada guru Bimbingan dan Konseling (BK) yang bernama Sudartik, S.Pd bahwasanya di SMA Negeri Darussholah terdapat siswa yang mengalami perilaku 
kecemasan sosial seperti: rasa cemas, gugup, takut, dan gelisah. Hasil wawancara juga menunjukkan bahwa guru BK atau pihak sekolah sudah melakukan upaya untuk mereduksi kecemasan siswa antara lain memberikan motivasi, membimbing, dan mendorong siswa agar mempunyai rasa percaya diri. Namun, hal ini dirasa belum efektif untuk menangani berbagai bentuk kecemasan sosial yang terjadi pada siswa di sekolah.

Tingkat kecemasan sosial yang dihadapi oleh siswa perlu diidentifikasi sejak awal, sehingga didapatkan data yang kongkrit tentang kecemasan sosial. Data tersebut dapat digunakan sebagai acuan dalam merancang program sebagai upaya intervensi yang nantinya digunakan untuk mereduksi kecemasan sosial siswa. Salah satu cara untuk merdeduksi kecemasan sosial yaitu layanan konseling Cognitive behavior yang diharapkan siswa dapat memahami dan mengetahui apa yang menjadi penyebab dirinya memiliki tingkat kecemasan sosial yang tinggi. Layanan konseling Cognitive behavior sebagai upaya bantuan untuk dapat memecahkan masalah siswa, teknik cognitive restructuring adalah salah satu teknik dalam layanan komseling cognitve behavior yang digunakan untuk membantu siswa untuk mereduksi kecemasan sosial siswa.

Teknik cognitive restructuring dikembangkan oleh Meicenboum, yang terpusat pada pesan negative yang disampaikan oleh orang kepada diri sendiri dan cenderung melumpuhkan kreatifnya dan menghambat dalam mengambil tindakan penyesuaian diri yang realistis. Menurut pandangan Meicenboum bahwa orang yang mendengarkan diri sendiri yang sama-sama menciptakan suatu dialog internal yang berkesan pada pendengaran pesan yang negatif dari diri sendiri. Dialog internal tersebut berisi penialian negatif pada diri sendiri yang akan membuat orang gelisah dalam menghadapi tantangan hidup dan kurang mampu mengambil tindakan penyesuaian diri yang tepat.

Di dalam konseling Cognitive behavior dengan teknik Cognitive Restructuring terdapat konsep dasar restrukturisasi kognitif adalah proses belajar untuk menyangkal distorsi kognitif atau kesalahan berpikir, dengan tujuan menggantikan pikiran seseorang yang tidak rasional, keyakinan kontra-faktual yang akurat dan dominan. Restrukturisasi kognitif adalah suatu cara untuk menata kembali pikiran yang menimbulkan atau menyebabkan irrasional pada individu sehingga berakibat adanya penyesuaian diri yang rendah. Dasar pemikiran yang digunakan dalam restrukturisasi kognitif adalah upaya untuk memperkuat keyakinan dan kepercayaan yang realistis. Tujuannya (1) mengubah keyakinan-keyakinan irrasional menjadi rasional, (2) mengurangi pikiran-pikiran negatif, dan (3) mengubah proses berpikir disfungsional, (Burns dalam Aryani, 2008).

\section{KAJIAN LITERATUR DAN PENGEMBANGAN HIPOTESIS}

Menurut Aaron T Beck (1964) mendefinisikan Cognitive Behaviour Therapy (CBT) sebagai pendekatan konseling yang dirancang untuk menyelesaikan permasalahan konseli pada saat ini dengan cara melakukan restrukturisasi kognitif dan perilaku yang menyimpang. Pendekatan ini didasarkan pada formulasi kognitif, keyakinan dan strategi perilaku yang mengganggu. Proses konseling didasarkan pada konseptualisasi atau pemahaman konseli atas keyakinan khusus dan pola perilaku konseli. Harapan dari CBT yaitu munculnya restrukturiasasi kognitif dan system kepercayaan untuk membawa perubahan ke arah yang lebih baik.

\section{Cognitive-Behavior Therapy (Corey,}

2012) merupakan pendekatan terapi yang yang menitik beratkan pada restrukturisasi atau pembenahan kognitif yang menyimpang akibat kejadian yang merugikan dirinya baik secara fisik ataupun psikis. CBT merupakan terapi 
yang dilakukan untuk meningkatkan dan merawat kesehatan mental. Terapi ini akan diarahkan kepada modifikasi fungsi berfikir, merasa dan bertindak, dengan mengunakan otak sebagai psikoanalisa, pengambilan keputusan, bertanya, bertindak, dan memutuskan kembali. Sedangkan pendekatan behavioral diarahkan untuk membangun hubungan yang baik antara situasi permasalahan dengan kebiasaan mereaksi permasalahan. Tujuan dari CBT yaitu mengajak individu untuk belajar mengubah perilaku, menenangkan pikiran dan tubuh sehingga merasa lebih baik, berpikir lebih jelas dan membantu membuat keputusan yang tepat. Hingga pada akhirnya dengan CBT diharapkan dapat membantu siswa dalam menyelaraskan pikiran, merasa dan bertindak.

Konsep dasar restrukturisasi kognitif adalah proses belajar untuk menyangkal distorsi kognitif atau kesa-lahan berpikir, dengan tujuan menggantikan pikiran seseorang yang tidak rasional, keyakinan kontra-faktual yang akurat dan dominan. Restrukturisasi kognitif adalah suatu cara untuk menata kembali pikiran yang menimbulkan atau menyebabkan irrasional pada individu sehingga berakibat adanya penyesuaian diri yang rendah. Dasar pemikiran yang digunakan dalam restrukturisasi kognitif adalah upaya untuk memperkuat keyakinan dan kepercayaan yang realistis. Tujuannya mengubah keyakinan-keyakinan irasional menjadi rasional, mengurangi pikiran-pikiran negatif, dan mengubah proses berpikir disfungsional, (Burns dalam Aryani, 2008). Restrukturisasi kognitif merupakan salah satu teknik yang berfokus pada modifikasi pikiran-pikiran yang maladaptif pada individu. Kecemasan sosial adalah istilah untuk ketakutan, masa gugup dan kecemasan yang dirasakan seseorang saat melaukan interaksi sosial, dengan orang lain (Gilian butler, 2008). Kecemasan sosial "menyerang” saat seseorang berpikir jika remaja melakukan sesuatu, remaja akan diberi label negaitif oleh orang lain atau berpikir dirinya akan melakukan sesuatu yang memalukan dihadapan orang lain.

Menurut Comier dan Comier, bahwa cognitive restructuring $(\mathrm{CR})$ pada awalnya diusulkan oleh Lazarus, dan berakar pada rational emotive therapy (RET) yang dikembamkan oleh Ellis. CR memusatkan perhatian pada upaya mengidentifikasi dan mengubah pikiran-pikiran atau pernyataan diri negatif dan keyakinan-keyakinan konseli yang tidak rasional. $\mathrm{CR}$ menggunakan asumsi bahasanya respons-respons perilaku dan emosional yang tidak adaptif dipengaruhi oleh keyakinan, sikap, dan persepsi (kognisi) konseli.

Kecemasan sosial adalah istilah untuk ketakutan, masa gugup dan kecemasan yang dirasakan seseorang saat melaukan interaksi sosial, dengan orang lain (Gilian butler, 2008). Kecemasan sosial "menyerang" saat seseorang berpikir jika remaja melakukan sesuatu, remaja akan diberi label negaitif oleh orang lain atau berpikir dirinya akan melakukan sesuatu yang memalukan dihadapan orang lain. Priest (dalam Safaria 2009) kecemasan sosial adalah: "ketakutan dan kecemasan dihakimi dan dievaluasi secara negatif oleh orang lain, yang mengarah pada perasaan tidak kuat, malu diri, merasa bodoh, dan depresi bahkan ketika sebenarnya mereka tampil baik dalam interaksi sosial". Dari penjelasan ahli tersebut dapat dijabarkan adapun masalahmasalah sosial yang dialami remaja diantaranya tidak suka dikritik, tidak memiliki etika dalam bergaul, kurang berminat dalam mengikuti kegiatan sosial, malu berteman dengan lawan jenis, dan sikap kurang positif terhadap pernikahan dan hidup berkeluarga.

Hipotesis yang diharapkan dalam penelitian ini adalah Hipotesis I berbunyi : Ha. Konseling Cognitive Behavior efektif untuk mengurangi Kecemasan Sosial siswa. Penelitian yang akan dilakukan ini selain menggunakan buku-buku dan artikel internet 
sebagi leteratur, juga merujuk pada beberapa penelitian terdahulu yang berkaitan. Berikut ini merupakan penelitian terdahulu yang relevan tentang kecemasan sosial.

Dalam jurnal penelitian Yanti Supri dengan judul "Hubungan antara Kecemasan Belajar dengan Motovasi Belajar Siswa (2013)". Kecemasan merupakan istilah yang, menggambarkan keadaan khawatir, gelisah, takut, tidak tenteram, dan sebagainya yang disertai dengan berbagai keluhan fisik. Hal ini didukung oleh Maramis (1980) yang mengatakan kecemasan adalah suatu ketegangan, rasa tidak aman, kekhawatiran yang timbul karena dirasakan akan mengalami kejadian yang tidak menyenangkan. Sampai batas tertentu perasaan cemas dapat dikatakan normal sebagai tanda atau isyarat untuk dapat lebih waspada bahwa ada suatu bahaya yang mengancam.

Dalam jurnal penelitian Prawoto Yulius Beni dengan judul "Hubungan Antara Konsep Diri Dengan Kecemasan Sosial Pada Remaja Kelas XI SMA KRISTEN 2 Surakarta (2010)". Kecemasan sosial diartikan sebagai ketakutan dihakimi dan dievaluasi secara negatif oleh orang lain, mendorong ke arah merasa kekurangan, kebingungan, penghinaan, dan tekanan. Kecemasan ini muncul pada masa remaja ketika kesadaran sosial dan pergaulan dengan orang lain merupakan hal yang penting dalam kehidupan seorang remaja. Ada banyak faktor yang melatarbelakangi kecemasan sosial pada remaja, salah satunya adalah konsep diri. Konsep diri mempunyai peranan penting dalam menentukan perilaku individu. Bagaimana individu memandang dirinya akan tampak dari seluruh perilaku. Penelitian ini bertujuan untuk mengetahui hubungan antara konsep diri dengan kecemasan sosial pada remaja. Metode dalam penelitian ini menggunakan pendekatan kuantitatif. Subjek penelitian diambil dengan teknik cluster random sampling. Alat pengumpulan data yang digunakan adalah skala konsep diri dan skala kecemasan sosial.
Analisis data menggunakan teknik korelasi product moment. Hasil perhitungan menggunakan korelasi product moment menunjukkan korelasi rx_y sebesar - 0,547 pada taraf signifikan $\mathrm{p}<0,05$. Artinya ada korelasi negatif yang signifikan antara konsep diri dengan kecemasan sosial pada remaja. Selain itu berdasarkan hasil analisis data diketahui ada hubungan yang signifikan secara statistik antara konsep diri dengan kecemasan sosial pada remaja ditunjukkan dengan nilai Fregresi $=18,39$ dengan $r<0,05$. Kontribusi konsep diri terhadap kecemasan sosial dapat dilihat dari hasil kuadrat nilai korelasi (R2) atau koefisien determinan (R Square) sebesar 0,300 atau $30 \%$ yang berarti masih terdapat $70 \%$ faktor lain yang mempengaruhi kecemasan sosial selain konsep diri.

Dalam jurnal penelitian Rizkiawati Rini dengan judul "Mengatasi Masalah Distorsi Kognitif Pada Klien Usia Remaja dengan Metode Cognitive Restructuring Form (2016)". Remaja merupakan suatu masa transisi dari anak-anak menuju dewasa. Mereka cenderung ingin mencari jati dirinya sendiri. Dalam proses tersebut seringkali mereka bertindak tanpa memikirkan dampak dari yang dilakukannya. Subyek penelitian adalah salah satu siswa kelas $\mathrm{X}$ SMAN Jatinangor yang memiliki masalah distorsi kognitif. Masalah tersebut berawal dari suasana rumah yang tidak membuatnya nyaman. Sehingga seringkali menimbulkan masalah-masalah baru dalam kehidupan sehari-harinya. Distorsi kognitif sendiri merupakan suatu cara berpikir seseorang yang berlebihan dan tidak rasional terhadap suatu hal atau masalah. Melihat masalah distorsi kognitif tersebut maka diperlukan pendampingan individual ini untuk membantu klien mengatasi permasalahan distorsi kognitifnya. Metode yang akan diberikan adalah dengan menggunakan Cognitif Restructuring Form (CRF). Tujuan pendampingan ini yaitu untuk mengatasi dari masalah distorsi kognitif. Metode tersebut 


\section{FKIP Universitas PGRI Banyuwangi Seminar Nasional \\ Pendidikan Budaya dan Sejarah: "Dibalik Revitalisasi Budaya" \\ ISBN: 978-602-72362-7-1}

diterapkan selama satu minggu dan hasilnya terlihat adanya perubahan yang baik.

\section{METODE PENELITIAN}

Penelitian ini dilakukan diwilayah Singojuruh Kabupaten Banyuwangi. Populasi penelitian adalah 102 pelajar SMA yang berusia 15-17 tahun, berjenis kelamin laki-laki dan perempuan dan pada saat penelitian berlangsung masih berstatus aktif sebagi siswa dan siswi di SMA di wilayah Singojuruh. Sebanyak 3 kelas berpartisipasi dalam penelitian ini, siswa-siswi yang berpartisipasi dalam penelitian ini adalah kelas X IPA 1, X IPA 3, dan X IPA 5. Metode pengumpulan data ini terdapat dua jenis metode Pengumpulan data yaitu metode pengumpulan data utama dan metode pengumpulan data pelengkap, metode pengumpulan data utama berupa kuesioner yang akan disebar pada siswa sedangkan metode data pelengkap berupa observasi dan wawancara.

Metode penelitian yang pertama adalah teknik analisis deskriptif, data instrumen kecemasan sosial dianalisis secara deskriptif dan dinyatakan dengan jenjang kualifikasi. Jenjang kualifikasi dikategorikan berdasarkan skor rata-rata $(\bar{X})$, mean ideal $(\mathrm{Mi})$, dan standar deviasi ideal (SDi). Setelah itu dilanjut dengan uji prasyarat yang terdiri dari uji normalitas dan uji homogenitas, dimana uji normalitas merupakan sebaran data dilakukan untuk meyakinkan bahwa data yang dihasilkan dalam penelitian benar-benar berdistribusi normal, sehingga uji hipotesis dapat dilakukan dan uji homogenitas digunakan untuk mengetahui apakah kelompok-kelompok sampel berasal dari polulasi yang sama.

Bila uji prasyarat anarkis diatas telah dilakukan maka dapat dilanjutkan dengan uji hipotesis sebagai langkah labih lanjut dalam penelitian ini, dilakukan suatu prosedur analisis terhadap data-data yang diperoleh peneliti. Tujuan dari analisis data ini adalah mengungkapkan apa yang ingin diketahui dari penelitian ini. Dalam menganalisis data yang diperoleh selama melakukan penelitian, penulis menggunakan dua analisis statistik, antara lain (1) analisis statistik correlated data/paired sampel t-test dan (2) analisis statistik uncorrelated data/independent sampel t-test. Dasar pengambilan keputusannya adalah : (1) Jika t hitung > t tabel, maka Ho ditolak (2) Jika t hitung < t tabel, maka Ho diterima .Berdasarkan nilai probabilitasnya : (1) Jika probabilitas > 0,05 maka Ho diterima (2) Jika probabilitas $<0,05$ maka Ho ditolak

\section{RANCANGAN}

Penelitian ini merupakan quasi experimental (eksperimen semu), dengan menggunakan rancangan Non Equivalent Pretest-Posttest Control Group Design. Rancangan control group design dipilih dengan pertimbangan bahwa dalam eksperimen semu, tidak memungkinkan untuk merandom subjek dalam kelompok populasi secara utuh. Selanjutnya pretest dan posttest berarti memberikan tes kepada subjek sebelum dan setelah perlakuan diberikan pada masingmasing kelompok. Rancangan ini dipilih karena penelitian ini merupakan penelitian 
terapeutik untuk mengetahui efektivitas atau pengaruh perlakuan terhadap variabel terikat. Artinya rancangan pretest dan posttest digunakan untuk mengetahui efektivitas konseling Cognitive Behavior untuk meningkatkan interaksi sosial asosiatif.

\begin{tabular}{|cccc|}
\hline E & O1 & X & O2 \\
\hline K & O1 & - & O2 \\
\hline
\end{tabular}

(Sumber: Dantes, 2012:97)

Keterangan :

E : kelompok eksperimen

$\mathrm{K}$ : kelompok kontrol

$\mathrm{X}$ : konseling kelompok CBT

- : konseling kelompok tanpa teknik khusus

O1 : pengamatan awal, berupa pre-test sebelum diberikan perlakuan.

$\mathrm{O} 2$ : pengamatan akhir, yaitu pemberian posttest setelah diberikan perlakuan

\section{REFERENSI}

Prawoto Yulius Beni. 2010. Hubungan Antara Konsep Diri Dengan Kecemasan Sosial Pada Remaja Kelas XI SMA KRISTEN 2 SURAKARTA. Skripsi. Tidak diterbitkan. Universitas Sebelas Maret Surakarta. http://eprints.uns.ac.id/5696/1/1354209082 01011001.pdf

Riza Wina Lova, Penerapan Terapi Perilaku Kognitif (Cognitive Behavior) Untuk Mengurangi Simtom pada Subjek yang Mengalami Gangguan Kecemasan Umum. Jurnal, Universitas Buana Perjuangan Karawang. http://journal.ubpkarawang.ac.id/index.php/ Psikologi/article/viewFile/36/35

Sugiyono. 2012. statiska untuk penelitian. Bandung: Alfabeta.

Sugiyono. 2010. Metode penelitian pendidikan (Pendekatan Kuantitatif Kualitatif dan $R \& D)$. Bandung : Alfabeta.

Yanti Supri. 2013. Hubungan Antara Kecemasan Belajar dengan Motivasi Belajar Siswa. Jurnal, http://ejournal.unp.ac.id/index.php/konselor /article/download/1242/6003 